Reprod. Nutr. Dévelop., 1980, 20 (3 A), 665-672.

\title{
A seasonal study of pinealocytes in the 13-lined ground squirrel, Spermophilus tridecemlineatus
}

\author{
par J. A. MCNULTY, Teresa A. DOMBROWSKI, Wilma A. SPURRIER \\ Departments of Anotomy and Physiology, Loyola University \\ Stritch School of Medicine, 2160 S. First Avenue, Maywood, Illinois 60153 USA.
}

\begin{abstract}
Summary. A quantitative histological study of pinealocytes in the 13-lined ground squirrel, Spermophilus tridecemlineafus, was conducted over a period of one year. Consistent and statistically significant seasonal differences were found in nuclear and nucleolar dimensions suggesting a circannual rhythm in the metabolism of these cells. Annual peaks occurred during hibernation, whereas the nadirs occurred during the period of sexual activity. Differences between sexes in any season were not statistically significant. An inverse relationship between nuclear and nucleolar size and the normal sexual cycle suggests that reproduction in this species may be mediated by the pineal gland. The question of what role, if any, the pineal gland plays in hibernation awaits further experimental evidence.
\end{abstract}

\section{Introduction.}

A functional relationship between the pineal gland and reproduction in certain mammals has gained considerable experimental support in recent years (Johnson and Reiter, 1978 ; Reiter, 1978). Of particular interest is the hypothesis that the pineal gland mediates the effects of changing light : dark cycles on gonadal maturation in those animals which reproduce seasonally (Reiter, 1974). Previous investigators have demonstrated seasonal changes in the morphology and enzymatic activity of the pineal gland in several species including the dormouse (Legait ef al., 1975), a hyrax (Quay and Millar, 1973), a hare (Lincoln, 1976), a ground squirrel (Ellis and Balph, 1976), two species of hibernating bats (Quay, 1976), the golden hamster (Mogler, 1958), and the pony (Wesson ef al., 1979). These studies have generally supported the concept that the pineal gland is most active during those times of the year when the animals are sexually quiescent. In this paper we present the results of a circannual study on nuclear and nucleolar dimensions in pinealocytes of the 13-lined ground squirrel, Spermophilus tridecemlineatus. Pinealocytes in this species have been described as being homogeneous with an ultrastructure similar to that of other rodents (Matsushima and Reiter, 1975 ; Povlishock ef al., 1975).

Address correspondence to : Dr. John A. McNulty, Department of Anatomy, Loyola University Medical Center, 2160 S. First Avenue, Maywood, Illinois 60153 U. S. A. 
The 13-lined ground squirrel is normally reproductively active from the latter part of March or early April through June (Foster et al., 1939 ; Johnson ef al., 1933). This sexual cycle is generally maintained under laboratory conditions (Johnson ef al., 1933). Beginning on or about September, squirrels enter their burrows and hibernate until the spring reproductive season.

\section{Materials and methods.}

A total of 51 animals ( 24 males and 27 females) between one and two years of age were sacrificed during every month of the year except July. The day of the month was kept constant so as to equally space the samples. In addition, all samples were taken at approximately the same time of day (1000-1 $200 \mathrm{hrs})$ to minimize the influence of circadian rhythms. Animals were housed under normal laboratory conditions with respect to both light and temperature. Between the months of October through late February or early March they were allowed to hibernate in a cold room maintained at $5 \circ \mathrm{C}$. The cold room was kept in darkness except for a brief period each day during which time the animals were cared for.

Squirrels were killed by decapitation and the pineal gland immersion fixed with 4 p. 100 glutaraldehyde in monophosphate buffer $(330 \mathrm{mOsm}, \mathrm{pH} \mathrm{7.4)}$ for a period of one hour. Following a brief buffer wash, the tissue was post-fixed in 1 p. 100 osmium tetroxide in phosphate buffer for one hour, dehydrated in a graded series of acetone and embedded in Araldite 502 plastic resin. Sections from near the central region of the pineal gland were cut at $1 \mu \mathrm{m}$, stained with toluidine blue, photographed, and projected onto a screen using a Nikon Profile Projector at a final magnification of $2000 \times$. For each specimen, nuclear profiles of 30 pinealocytes, which included one or more nucleoli, were systematically sampled and the greatest dimension measured. Nucleoli of these same pinealocytes were also measured. In those cases where more than one nucleolus was present the largest was measured.

For this study, the year was divided into four periods which reflect both the reproductive and hibernation cycle of the animal as determined by Foster ef al. (1939). The months August through October represented the period of pre-hibernation ; November through January the period of hibernation; February and March the period of arousal from hibernation ; April through June the period of sexual activity. As deduced by descent of the testes into the scrotal sacs and enlargement of the vulva, the specimens used in this study followed the normal sexual cycle. Because of the small sample size in any month, mean values for each specimen were grouped accoiding to these periods by sex and both sexes combined. Means and standard errors of these grouped means were calculated. Seasonal means of combined sexes were statistically evaluated using a one-way analysis of variance test.

\section{Results.}

Pinealocytes were the most numerous cell type present in the ground squirrel pineal gland and were easily identified by their large nuclei, containing little heterochromatin, and prominent nucleoli. When plotted, nuclear size, as determined by 
the greatest dimension, showed seasonal changes with peak values occurring during hibernation while minimum values coincided with that time of the year when the animals are normally sexually active (fig. 1). Analysis of variance of combined sexes gave $\mathrm{P}<0.001$. It was calculated that there was a 14 p. 100 range between maximum December and minimum May values (table 1). Differences between sexes in any season were not significant. However, nuclear size in females tended to peak earlier (November) than in males (December). Likewise, the minimum value for females occurred in March, whereas that of males occurred during April and May. As seen in table 1 , there was a decrease in nuclear dimension (particularly in females) during the month of October.

\section{TABLE 1}

Monthly means ( \pm 1 SEM) for nuclear and nucleolar diameters are listed by sex and both sexes combined. Numbers of animals in each group is in parentheses to the right

\begin{tabular}{|c|c|c|c|c|}
\hline \multirow[t]{2}{*}{ Month } & \multirow{2}{*}{$\begin{array}{l}\begin{array}{l}\text { Nuclear } \\
\text { diameter }\end{array} \\
9.45(0.14)\end{array}$} & \multirow{2}{*}{$\begin{array}{l}\begin{array}{l}\text { Nucleolar } \\
\text { diameter }\end{array} \\
2.30(0.06)\end{array}$} & \multicolumn{2}{|c|}{$\begin{array}{l}\text { Sex (number of } \\
\text { animals) }\end{array}$} \\
\hline & & & males & (3) \\
\hline \multirow[t]{3}{*}{ August } & $9.22(0.14)$ & $2.45(0.10)$ & females & (3) \\
\hline & $9.34(0.09)$ & $2.38(0.06)$ & combined & (6) \\
\hline & $9.35(-)$ & $2.51(-)$ & males & (1) \\
\hline \multirow[t]{3}{*}{ September } & $9.59(0.04)$ & $2.52(0.26)$ & females & (2) \\
\hline & $9.51(0.08)$ & $2.52(0.15)$ & combined & (3) \\
\hline & $9.14(0.11)$ & $2.33(0.03)$ & males & (2) \\
\hline \multirow[t]{3}{*}{ October } & $8.76(0.02)$ & $2.08(0.03)$ & females & (2) \\
\hline & $8.95(0.12)$ & $2.21(0.02)$ & combined & (4) \\
\hline & $9.34(0.31)$ & $2.59(0.20)$ & males & (2) \\
\hline \multirow{3}{*}{ November } & $9.82(0.09)$ & $2.40(0.05)$ & females & (2) \\
\hline & $9.58(0.19)$ & $2.50(0.09)$ & combined & (4) \\
\hline & $10.29(0.36)$ & $2.63(0.01)$ & males & (3) \\
\hline \multirow[t]{3}{*}{ December } & $9.58(-)$ & $2.62(-)$ & females & (1) \\
\hline & $9.93(0.30)$ & $2.63(0.10)$ & combined & (4) \\
\hline & $9.38(0.23)$ & $2.70(0.01)$ & males & (2) \\
\hline \multirow[t]{3}{*}{ January } & $9.57(0.13)$ & $2.33(0.06)$ & females & (2) \\
\hline & $9.47(0.12)$ & $2.52(0.05)$ & combined & (4) \\
\hline & $9.42(0.06)$ & $2.22(0.03)$ & males & (2) \\
\hline \multirow[t]{3}{*}{ February } & $9.38(0.20)$ & $2.25(0.05)$ & females & (4) \\
\hline & $9.39(0.13)$ & $2.24(0.03)$ & combined & (6) \\
\hline & $8.96(0.05)$ & $2.27(0.12)$ & males & (4) \\
\hline \multirow[t]{3}{*}{ March } & $8.71(0.14)$ & $2.18(0.18)$ & females & (4) \\
\hline & $8.84(0.08)$ & $2.23(0.10)$ & combined & (8) \\
\hline & $8.59(0.05)$ & $1.86(0.03)$ & males & (2) \\
\hline \multirow[t]{3}{*}{ April } & $8.93(0.30)$ & $2.04(0.09)$ & females & (2) \\
\hline & $8.74(0.17)$ & $1.95(0.04)$ & combined & (4) \\
\hline & $8.58(0.23)$ & $2.27(0.19)$ & males & (2) \\
\hline \multirow[t]{3}{*}{ May } & $8.87(0.17)$ & $2.12(0.04)$ & females & (2) \\
\hline & $8.72(0.14)$ & $2.20(0.08)$ & combined & (4) \\
\hline & $9.17(0.61)$ & $2.41(0.07)$ & males & (2) \\
\hline \multirow[t]{2}{*}{ June } & $9.07(0.04)$ & $2.20(0.11)$ & females & (2) \\
\hline & $9.12(0.25)$ & $2.31(0.07)$ & combined & (4) \\
\hline
\end{tabular}


The pattern for seasonal changes in the size of pinealocyte nucleoli essentially followed that of the nuclei. The largest nucleoli were present in pinealocytes of hibernating animals, the smallest occurred during the estrous phase of the reproductive cycle (fig. 2). Analysis of variance test gave $P<0.01$ with approximately a 35 p. 100 range between the maximum December and minimum April values for both sexes combined (table 1). Compared to the greatest nuclear dimension, there was a slight shift in peak nucleolar values; these peaks occurring during the months of December and January for females and males, respectively (table 1). Furthermore, there was a marked reduction in the size of nucleoli during the month of October, this decrease again being greater in females than in males (table 1).

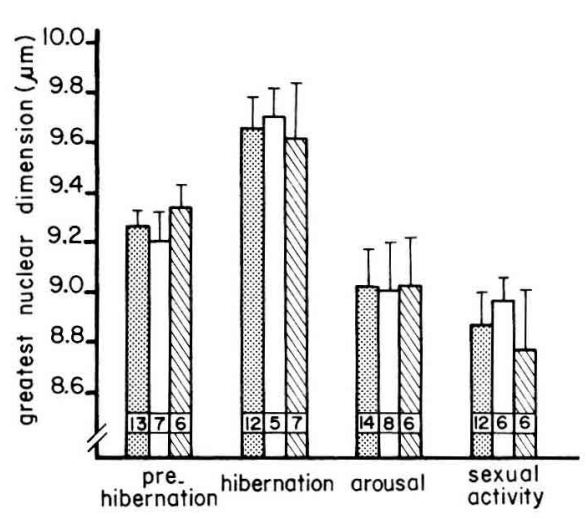

FIG. 1.

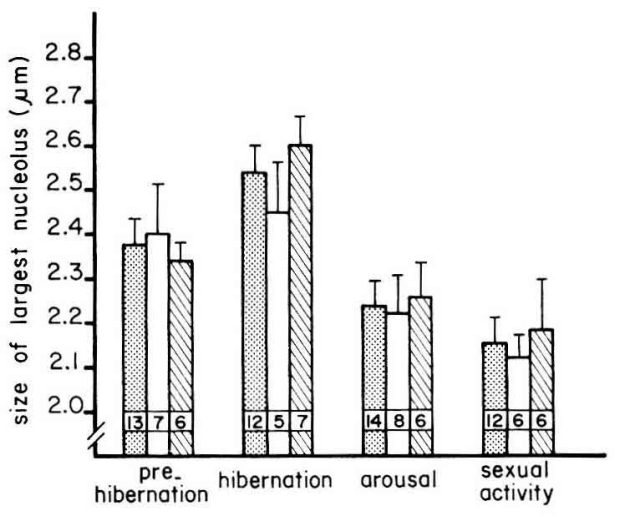

FIG. 2.

FIG. 1. - Means plus 1 standard error of greatest nuclear dimension of pinealocytes for each period. In both figures, the solid bar represents both sexes combined, the clear bar females, and the hatched bar males. Number of animals in each group is indicated at the bottom.

FIG. 2. - Means plus 1 standard error of largest nucleolus for each period.

\section{Discussion.}

The results of this study indicate that an annual rhythm occurs in both nuclear and nucleolar dimensions of pinealocytes in the 13-lined ground squirrel, $S$. fridecemlineatus. Since nuclear and nucleolar size are generally accepted as reflecting cellular function (Busch and Smetana, 1970 ; Rather, 1958), the present data suggest that metabolic activities of pinealocytes in this animal are seasonal. This suggestion is further substantiated by circadian studies on rat pinealocytes showing that peak nuclear and nucleolar sizes (Quay and Renzoni, 1966) are correlated to RNA and protein content of the pineal gland (Nir et al., 1971).

In this study, nuclear and nucleolar sizes were inversely related to the normal reproductive cycle, reaching their greatest dimensions during hibernation when the animals are sexually inactive. Numerous investigators have demonstrated a relationship between pineal gland function and gonadal maturation (see Reiter, 1978). These studies have shown that the pineal secretes antigonadotropic compounds with pineal activity reduced during the light phase of the light : dark cycle. It has been 
proposed, therefore, that a major function of the pineal gland is to synchronize sexual activity to changing daylength in those animals which reproduce seasonally (Reiter, 1974). That is, with shortening photoperiod following the summer solstice, pineal activity is postulated to be greatest, thereby inhibiting gonadal activity. In the case of $S$. tridecemlineatus, the animal is exposed to even greater periods of darkness since it hibernates in burrows during the fall and winter months.

Several studies have suggested that the pineal exerts its inhibitory effects on the gonads via hypothalamo-hypophyseal pathways in both rats and hamsters (Blask, 1978 ; Fraschini ef al., 1971). Although biochemical and physiological data demonstrating pineal-pituitary interactions are not available for this species, Hoffman and Zarrow (1958) found reduced basophilic activity (as judged by cell size and staining activity) in the pituitary of S. tridecemlineatus over the hibernating period. This activity increased rapidly during arousal and maintained high levels over the reproductive period. These seasonal changes in pituitary activity are opposite to those suggested for the pineal in this study.

Some comparisons can be made between the species in this study and seasonal studies on the pineal gland in other mammals. Using the hibernating ground squirrel, S. armatus, Ellis and Balph (1976) measured levels of the enzyme, hydroxyindoleO-methyltransferase (a marker enzyme for pineal activity), at three times of the year. The authors reported that levels of this enzyme were generally lowest during the breeding season and highest just prior to hibernation. It is not known if increased enzyme levels continued during hibernation, since samples from hibernating animals were not taken. Our results demonstrating seasonal changes in nucleolar size, which presumably are indicative of differences in the rate of protein synthesis, correlate well to changes in the level of this enzyme. In the hibernating dormouse, Glis glis, pinealocyte nuclear diameter was greatest during the period of hibernation and smallest during summer months (Legait ef al., 1975), a cycle similar to that observed in the 13lined ground squirrel. Quay (1976) found significant seasonal differences in pinealocyte nuclear and nucleolar diameters in two species of bats. Maximal and minimal sizes had seasonal ranges of 6-13 p. 100 and 35 p. 100 for nuclei and nucleoli, respectively. These ranges are similar to those reported in the present study. In contrast to the ground squirrel, nucleolar size in these two species of bats was greatest during arousal and declined steadily through spring and summer months. Quay (1976) noted that during this time there is a steady increase in pituitary LH-cell activity in related species. Seasonal changes in the nuclei and nucleoli of pinealocytes have also been found to be inversely related to activity of the reproductive system in the golden hamster (Mogler, 1958), the male rock hyrax, Procavia capensis (Quay and Millar, 1973), and a hare (Lincoln, 1976).

In addition to reproduction, the 13-lined ground squirrel undergoes an equally important seasonally timed event, namely hibernation. Since both nuclear and nucleolar sizes were greatest during hibernation, it is conceivable that pinealocyte secretory products effect physiological functions other than reproduction during this time of the year. The observation that injections of melatonin, a pineal hormone, increased both the incidence and duration of hibernating bouts in the ground squirrel, S. lateralis (Palmer and Riedesel, 1976), is compelling evidence. On the other hand, Popova ef al. (1975) found serotonin content of the pineal gland in the hibernating ground squirrel, 
Cifellus erthrogenys major, to be half that measured in active, summer animals, suggesting reduced function of pinealocyles during hibernation. The complex physiology of the hibernating animal and the presumed interaction of various endocrine systems has led to considerable difficulty in elucidating many of the mechanisms of hibernation. Besides the gonads and pituitary, other endocrine organs such as the adrenal cortex and thyroid are regressed during hibernation (Kayser, 1961). In view of recent studies demonstrating pineal-mediation of both adrenal cortex and thyroid function (see Romijn, 1978), the question remains as to whether the pineal gland plays a role during the onset of hibernation by inhibiting endocrine activity of these glands.

Several authors have discussed the possibility of pineal participation in hibernation or cold adaptation. Miline ef al. (1970) found that when rats were exposed to cold temperatures $\left(3-10^{\circ} \mathrm{C}\right.$ ) within the range of a hibernating animal, the pineal gland underwent a number of structural changes including hypertrophy of pinealocyte nuclei and nucleoli. The authors concluded from their study that the pineal gland was stimulated by cold and therefore plays an integral role in adaptation of the animal to cold stress. In contrast, Quay (1978) reported a significant increase particularly in the size of nucleoli with exposure of collared lemmings to elevated temperatures. These species differences in the response of pinealocytes to environmental temperatures might be expected considering their diverse ecologies. In an earlier study on seasonal changes in pinealocytes of two species of bats, Quay (1976) proposed that pineal regulation of the sympatheto-adrenomedullary system might contribute to the arousal of bats from hibernation. This study was based on a study of the rat, where increased nocfurnal levels of adrenomedullary dopamine-beta-hydroxylase, which catalyzes the conversion of dopamine to norepinephrine, were found to be pineal dependent (Banerji and Quay, 1976). Other target tissues which have been proposed as being under pineal confrol during hibernation or torpor include the heart (Palmer and Riedesel, 1976) and brown adipose tissue (Heldmaier and Hoffman, 1974).

In summary, seasonal morphological changes in pinealocyte nuclei and nucleoli were found to be inversely related to the reproductive cycle of the 13-lined ground squirrel. These findings generally agree with observations on other mammals and suggest that sexual activity in this species may be pineal-mediated. However, the fact that numerous physiological changes (i. e., hibernation) occur during that time of the year when the pineal gland is presumably most active, introduces questions regarding other possible roles of the pineal in the biology of this animal.

Reçu en aoof 1979.

Accepté en octobre 1979.

Acknowledgements. - This study was supported by a BRSG (NIH) from the Stritch School of Medicine and USPHS Grant HL-08682.

Résumé. Une éłude histologique quantifative des pinéalocytes du Spermophile à treize bandes, Spermophilus tridecemlineatus, a été effectuée au cours d'un cycle annuel. Les dimensions nucléaires et nucléolaires montrent de nettes différences saisonnières, statistiquement significatives, suggérant un rythme circannuel du métabolisme de ces cellules. Les pics annuels s'observent au cours de l'hibernation tandis que les minimums se situent au cours de la période d'activité sexuelle. Quelle que soit la saison, les différences entre sexes 
ne sont pas statistiquement significatives. La relation inverse entre les dimensions nucléaires et nucléolaires, ef le cycle sexuel normal suggère que la fonction de reproduction, chez cette espèce, peut être contrôlée par la glande pinéale. D'autres expériences sont nécessaires pour déterminer quel rôle joue éventuellement cette glande dans l'hibernation.

\section{References}

BANERJI T. K., QUAY W. B., 1976. Adrenal dopamine-B-hydroxylase activity : Twenty-four-hour rhythmicity and evidence for pineal control. Experientia, 32, 253-255.

BLASK D. E., 1978. Pineal-induced alterations in hypothalamic FRH activity independent of LRH in the male hamster (abst.). Anat. Rec., 190, 342.

BUSCH H., SMETANA K., 1970. The Nucleolus. Acad. Press, New York, 626 pp.

ELLIS L. G., BALPH D. F., 1976. Age and seasonal differences in the synthesis and metabolism of testosterone by testicular tissue and pineal HIOMT activity of the Uinta ground squirrel (Spermophilus armatus). Gen. comp. Endocrinol., 28, 42-51.

FOSTER M. A., FOSTER R. C., MEYER R. K., 1939. Hibernation and the endocrines. Endocrinology, 24, 603-612.

FRASCHINI F., COLLU R., MARTINI L., 1971. Mechanisms of inhibitory action of pineal principles on gonadotropin secretion, 259-273. In WOLSTENHOLME G. E. W., KNIGHT J., The Pineal Gland, Churchill Livingstone, London.

HELDMAIER G., HOFFMAN K., 1974. Melatonin stimulates growth of brown adipose tissue. Nature, 247, 224-225.

HOFFMAN R. A., ZARROW M. X., 1958. Seasonal changes in the basophilic cells of the pituitary gland of the ground squirrel (Citellus tridecemlineatus). Anat. Rec., 131, 727-735.

JOHNSON G. E., FOSTER M. A., COCO R. M., 1933. The sexual cycle of the thirteen-lined ground squirrel in the laboratory. Trans. Kans. Acad. Sci., 36, 250-269.

JOHNSON L. V., REITER R. J., 1978. The pineal gland and its effects on mammalian reproduction, 115-156. In REITER R. J., Progress in Reproductive Biology, Vol. 4, Karger, Basel.

KAYSER Ch., 1961. The Physiology of Natural Hibernation. 325 pp. Permagon Press, New York.

LEGAIT H., ROUX M., DUSSART G., RICHOUX J. P., CONTET-AUDONNEAU J. L., 1975. Données morphométriques sur la glande pinéale du loir (Glis glis) et du lérot (Eliomys quercinus) au cours du cycle annuel. C. R. Soc. Biol., 169, 132-136.

LINCOLN G. A., 1976. Seasonal changes in the pineal gland related to the reproductive cycle of the male hare, Lepus europaeus. J. Reprod. Fert., 46, 489-491.

MATSUSHIMA S., REITER R. J., 1975. Comparative ultrastructural studies of the pineal gland of rodents, 335-356. In HESS M., Electron Microscopic Concepts of Secretion, John Wiley and Sons, New York.

MILINE R., DEVECERSKI V., SIJACKI N., KRSTIC R., 1970. Pineal gland behavior as affected by cold. Hormones, 1, 321-331.

MOGLER R. K., 1958. Das Endokrine System oles Syrischer Goldhamsters (Mesocricetus aurafus auratus Waterhouse) unter Berucksichtigung des Naturlichen und Experimenteller Winterschlafs. Z. Morph. Ökol. Tiere, 47, 267-308.

NIR I., HIRSCHMANN N., SULMAN F. G., 1971. Diurnal rhythms of pineal nucleic acids and protein. Neuroendocrinology, 7, 271-277.

PALMER D. L., RIEDESEL M. L., 1976. Responses of whole-animal and isolated hearts of ground squirrels, Cifellus loteralis to melatonin. Comp. Biochem. Physiol., 53C, 69-72.

POPOVA N. K., KOLAEVA S. G., DIANOVA I. 1., 1975. State of the pineal gland during hibernation. Bull. exp. Biol. Med., 79, 467-468.

POVLISHOCK J. T., KRIEBEL R. M., SEIBEL H. R., 1975. A light and electron microscopic study of the pineal gland of the ground squirrel, Cifellus tridecemlineafus. Amer. J. Anot., 143, 465-484.

QUAY W. B., 1976. Seasonal cycle and physiological correlates of pinealocyle nuclear and nucleolar diameters in the bats, Myotis lucifugus and Myotis sodalis. Gen. comp. Endocrinol., 29, 369-375.

QUAY W. B., 1978. Quantitative morphology and environmental responses of the pineal gland in the collared lemming (Dicrostonyx groenlondieus). Amer. J. Anat., 153, 545-561.

QUAY W. B., MILLAR R. P., 1973. Cytological evidence for reduction in pinealocyte activity during seasonal sexual activity in the male rock hyrax. Procavia capensis. Amer. Zool., 13, 1288. 
QUAY W. B., RENZONI A., 1966. Twenty-four-hour rhythms in pineal mitotic activity and nuclear and nucleolar dimensions. Growth, 30, 315-324.

RATHER L. J., 1958. The significance of nuclear size in physiological and pathological processes. Ergeb. allg. Pathol. pathol. Anat., 38, 127-299.

REITER R. J., 1974. Circannual reproductive rhythms in mammals related to photoperiod and pineal function : A review. Chronobiologia, 1, 365-395.

REITER R. J., 1978. The Pineal, Vol. 3, 326 pp., Eden Press, Monireal.

ROMIJN H. J., 1978. Minireview : The pineal, a tranquillizing organ. Life Sci., 23, 2257-2274.

WESSON J. A., ORR E. L., QUAY W. B., GINTHER O. J., 1979. Seasonal relationships between pineal hydroxyindole-O-methyl-transferase (HIOMT) activity and reproductive status in the pony. Gen. comp. Endocrinol., 38, 46-52. 